\title{
Molecular detection of Bluetongue Virus (BTV) and Bovine Leukemia Virus (BLV) in uterine biopsies of dairy cows with or without reproductive problems
}

\section{Detecção molecular do Vírus da Língua Azul (BTV) e do Vírus da Leucemia bovina (BLV) em amostras de biópsia uterina de vacas leiteiras com e sem problemas reprodutivos}

\author{
Juliana Marques Bicalho ${ }^{1 *}$; Antônio Augusto Fonseca Júnior²; \\ Cairo Henrique Sousa de Oliveira ${ }^{3}$; Cláudia Fideles Resende ${ }^{4}$; \\ Telissa da Cunha Kassar ${ }^{5}$; Grazielle Cossenzo Florentino Galinari ${ }^{1}$; \\ André Penido Oliveira ${ }^{6}$; Livia de Lima Orzil17 Jenner Karlisson Pimenta dos Reis ${ }^{8}$; \\ Rômulo Cerqueira Leite ${ }^{8}$
}

\begin{abstract}
Reproductive performance of dairy cows has a direct impact on herd productivity. Infectious agents, such as Bluetongue Virus (BTV) and Bovine Leukemia Virus (BLV), are associated with reproductive failure. However, it remains unknown if these viruses are present in the uterus and cause gestational loss. This study used molecular methods to assess if BTV and BLV can be detected in the uterus of serologically positive dairy cows with a record of abortions, stillbirths and repeat breeding $(n=23)$ and without a record of reproductive problems $(n=23)$. The cows came from three dairy herds of the state of Minas Gerais, Brazil. BTV was not detected in any of the uterine biopsies. Proviral DNA of BLV was detected in $54.5 \%$ of the seropositive cows, but positivity for BLV in the uterus was not associated with the existence of reproductive problems. In conclusion, this study shows that BLV, but not BTV, is present in the uterus of seropositive cows, regardless of reproductive performance.
\end{abstract}

Key words: Bovines. Reproduction. Uterus. BTV. BLV.

\section{Resumo}

O desempenho reprodutivo das vacas leiteiras tem impacto direto na produtividade dos rebanhos. Agentes infecciosos como o Vírus da Língua Azul (BTV) e o Vírus da Leucemia Bovina (BLV) estão

\footnotetext{
${ }^{1}$ Mestres em Ciência Animal, Universidade Federal de Minas Gerais, UFMG, Belo Horizonte, MG, Brasil. E-mail:julianambicalho@, gmail.com; grazzicoss@gmail.com

${ }^{2}$ Fiscal Federal Agropecuário, Laboratório Nacional Agropecuário, LANAGRO, Pedro Leopoldo, MG, Brasil. E-mail: antonio. fonseca@lanagro.gov.br

3 Prof. Adjunto, Universidade Federal de Goiás, UFG, Goiânia, GO, Brasil. E-mail: cairo henrique@yahoo.com.br

${ }^{4}$ Discente, Curso de Mestrado em Ciência Animal, UFMG, Belo Horizonte, MG, Brasil. E-mail: claudiafideles91@hotmail.com

5 Discente, Curso de Doutorado em Ciência Animal, UFMG, Belo Horizonte, MG, Brasil. E-mail: tetekassar@gmail.com

${ }^{6}$ Pesquisador, Empresa de Pesquisa Agropecuária de Minas Gerais, EPAMIG, Uberaba, MG, Brasil. E-mail: andre.oliveira@ epamig.br

${ }^{7}$ Assistente de Laboratório, Laboratório Nacional Agropecuário, LANAGRO, Pedro Leopoldo, MG, Brasil. E-mail: liviaorzil@, yahoo.com.br

${ }^{8}$ Profs. Titular, UFMG, Belo Horizonte, MG, Brasil. E-mail: jenner@ufmg.br; romulocnpq@gmail.com

* Author for correspondence
} 
associados à ocorrência de falhas reprodutivas. Entretanto, não se sabe se estes vírus poderiam estar presentes no útero resultando nas perdas gestacionais. Este estudo utilizou métodos moleculares para investigar se os vírus BTV e BLV estão presentes no úterio de vacas leiteiras sorologicamente positivas com histórico de abortos, natimortos e repetição de cio $(n=23)$ e em vacas sem histórico de problema reprodutivos $(n=23)$ provenientes de três rebanhos leiteiros localizados no estado de Minas Gerais, Brasil. Não foi detectado BTV em nenhuma amostra de biópsia uterina. Por outro lado, o DNA proviral de BLV foi detectado no útero de $54.5 \%$ das vacas soropositivas, independentemente da ocorrência de problemas reprodutivos. Conclui-se que o vírus BLV, ao contrário do BTV está presente no útero de vacas soropositivas, entretanto, sem associação com o desempenho reprodutivo.

Palavras-chave: Bovinos. Reprodução. Útero. BTV. BLV.

\section{Introduction}

Productivity of dairy herds is intimately linked with the animals' reproductive performance. Delivery sets the beginning of a new lactation and the birth of heifers that allow for herd reposition (SANTOS et al., 2004). Each gestational loss in a dairy farm causes an estimated financial damage of \$2.333 (LEE; KIM, 2007). Reproductive loss is linked to several factors, including endocrine, genetic, metabolic or infectious alterations (DISKIN; MORRIS, 2008; WALSH et al., 2011).

Bluetongue virus (BTV) is an RNA virus that belongs to the Orbivirus gender and to the Reoviridae family (MELLOR; WITTMANN, 2002). A recent BTV-8 outbreak in Europe was associated with increased abortion and repeat breeding and with higher number of artificial inseminations per conception in affected herds (ELBERS et al., 2009; MARCEAU et al., 2014; NUSINOVICI et al., 2012a, 2012b; SANTMAN-BERENDS et al., 2010; ZANELLA et al., 2012).

Bovine leukemia virus (BLV) is a Deltaretrovirus from the Retroviridae family that causes enzootic bovine leukosis (EBL) (MILLER et al., 1969). How BLV affects animal reproductive performance remains unclear. Previous studies failed to find an effect of the infection on herd fertility (BRENNER et al., 1989; D'ANGELINO et al., 1998; HUBER et al, 1981; KALE et al., 2007). However, others have reported that the presence of the virus may be associated with fetal loss and presence of ovarian cysts (HEALD et al., 1992; JACOBS et al., 1991;
POLLARI et al., 1992; VANLEEUWEN et al., 2010).

Previous reports found that reproductive indicators are compromised in BTV and BLV seropositive herds. However, it remains unknown whether these agents are present in the uterus and if they directly cause reproductive problems. Therefore, this study aimed to test if BTV and BLV are present in the uterus of serologically positive cows and whether this is related with the incidence of abortions, stillbirths and repeat breeding.

\section{Materials and Methods}

Forty-six dairy cows from three different properties located in the state of Minas Gerais, Brazil, were used. Properties A $(n=12)$ and B $(n=10)$ had crossbred Holstein x Gyr and Holstein $\mathrm{x}$ Guzera cows and used bulls for reproduction. Property C $(n=24)$ contained Holstein cows and crossbred cows (Holstein x Gyr) and used fixedtime artificial insemination (FTAI). The cows included in this study could not be pregnant or have uterine pathologies. In addition, they had to be pluriparous and in good clinical condition with normal ovarian cycles. The Buffered Acidified Antigen test showed that all animals tested negative for Brucella abortus (BRASIL, 2006). All procedures were approved by the Ethics Committee for the Use of Animals from the Universidade Federal de Minas Gerais, MG, Brazil (Protocol number 68/2014). 
Animals were classified in groups according to the respective reproductive record provided by the properties. Group $1(\mathrm{n}=23)$ was composed of animals that had a record of abortion, stillbirths and a number of services per conception equal or greater than 5. Group $2(n=23)$ was composed of cows without a reproductive problem. Each property used the same number of animals from groups 1 and 2 .

Serological tests were used to determine animal seropositivity for the studied viruses. BLV was diagnosed using the agar gel immuno-diffusion test (AGID), according to Miller and van der Maaten (1976), with the commercial antigen (Tecpar), according to the manufacturer's instructions. BTV was diagnosed with a similar methodology, using a $1 \%$ agarose gel in a buffered salt solution $(\mathrm{NaCl}$ $0.9 \%$ ) and the VLA-4 antigen (BTV serotype 4) produced by the Laboratório Pesquisa em Virologia Animal (UFMG).

Prior to the uterine biopsy procedure, gynecological examination (by rectal examination) and transrectal ultrasonography were performed to exclude recent pregnancy cases. Afterwards, an epidural anesthesia of lidocaine hydrochloride $2 \%$ (3-5 $\mathrm{ml}$ ) was provided to the intervertebral space, between the first and second coccygeal vertebra. The perianal and vulvar regions were then cleaned with water and dried with paper towel. The material was collected using a replica of the Hauptner ${ }^{\circledR}$ biopsy clamp protected with a disposable sanitary material. The procedure consisted in introducing the clamp through the vagina and cervix, guided through rectal manipulation. The sanitary material was removed once the uterus was reached. The clamp was guided through the ipsilateral uterine horn towards the corpus luteum of the ovary. Upon its absence, the biopsy was performed in the left uterine horn, the site with highest embryonic mortality (FERREIRA et al., 1988). To perform the biopsy, gentle digital pressure was applied (via transrectal) over the uterine tissue of interest, guiding it to meet the extremity of the open clamp.
The clamp was then closed and pulled to extract the fragment. The clamp was washed with water and soap and disinfected with $70 \%$ alcohol between the animals. The same person performed all uterine biopsies. Collected fragments were placed in RNAse/DNAse-free cryotubes (Sarsdedt), immersed in liquid nitrogen $\left(-196^{\circ} \mathrm{C}\right)$ at the farm and stored at $-80^{\circ} \mathrm{C}$.

Disposable sterilized material was used to cut the uterine tissue samples in laminar flow cabinets. The QIAmp DNA Mini Kit (Qiagen) or the SV Total RNA Isolation System (Promega) were used to extract DNA or RNA from each tissue portion, respectively, following the manufacturer's instructions. To optimize the procedures, the tissues were macerated in the respective lysis buffers using sterilized microtube pestels. Detection of GAPDH, as described by Oliveira et al. (2013), and ACTB ( $\beta$-actin), as described by Bielanski et al. (2009), was used to confirm the DNA extraction efficiency.

Nested PCR was performed to detect the env region of the BLV proviral DNA, as described by OIE (2010). The external and internal amplification products had molecular weights of $440 \mathrm{bp}$ and $341 \mathrm{bp}$, respectively. The commercial kit Go taq Flexi $^{\circledR}$ DNA Polymerase (Promega) was used and the amplifications were performed using the thermocycler Veriti Thermal Cycler (Applied Biosystems). The final amplified products were separated by gel electrophoresis - $10 \mu \mathrm{L}$ of the final products were loaded in a $1.5 \%$ agarose $(\mathrm{p} / \mathrm{v})$ gel - and visualized by ethidium bromide staining $(1.5 \mathrm{mg} / \mathrm{mL})$. Comparing the gel with the standard molecular pattern of 100 base pairs identified the expected products. DNA extracted from an FLK (fetal lamb kidney) cellular lineage persistently infected with BLV was used as positive control.

BTV RNA was detected by quantitative reverse transcriptase PCR (RT-PCR), as described by Shaw et al. (2007). Complementary DNA was synthetized using the TaqMan ${ }^{\circledR}$ Fast Virus 1-Step Master Mix (Applied Biosystems). Samples 
provided by the Laboratory for Diagnosis of Viral Diseases (LANAGRO, Minas Gerais) were used as positive controls. The reactions were carried in a LightCycler $^{\circledR} 480$ (Roche).

The bands of samples considered positive were cut off from the agarose gel and DNA extraction was performed using the Axygen ${ }^{\mathrm{TM}}$ Axyprep $^{\mathrm{TM}}$ DNA Gel Extraction Kit (Axygen). Samples were sequenced (Sanger method) in a 3500 Genetic Analyzer (Applied Biosystems) by the Laboratory for Aquatic Animal Diseases (Aquacen) from the Veterinary School of UFMG. The sequences were grouped using DNA Baser ${ }^{\circledR}$ and compared (in terms of similarity) to the sequence databases of the National Center for Biotechnology Information using the Basic Local Alignment Search Tool $\left(\mathrm{NCBI}, \mathrm{BLAST}^{\circledR}\right)$.

Fisher's Exact Test $(p<0.05)$ - STATA program, Version 12.1 (StataCorp) - was used to determine if the presence of infectious agents in the uterus influences the incidence of reproductive problems.

\section{Results and Discussion}

The serological tests found that $89.1 \%(41 / 46)$ of the animals were seropositive for BTV and 95.6\% (44/46) were seropositive for BLV. BTV RNA could not be detected in any of the uterine biopsies (data not shown). Serological detection of BTV does not necessarily imply that animals are undergoing a period of active infection, as the levels of antibodies remain elevated for up to three years after the viral infection (PEARSON; JOCHIM, 1979). Only studies conducted in experimentally infected animals reported presence of the virus in the uterus (these studies isolated cows, performed in situ hybridization in female dogs and RT-PCR in goats) (BROWN et al., 1996; COETZEE et al., 2013; DE LA CONCHA-BERMEJILLO et al., 1993).

Nested PCR detected BLV proviral DNA in the uterine tissue of $52.2 \%(24 / 46)$ of the animals.
Sequencing showed that there was $94-100 \%$ similarity with sequences from the env region of BLV isolates (GenBank: FJ808579.1; DQ059421.1; JN254639; JN254638.1). This is the first study reporting detection of the virus in the uterus of a large number of naturally infected animals. The same PCR was used by Klintevall et al. (1994) to detect the presence of BLV in the uterus of $100 \%$ $(5 / 5)$ of the experimentally infected heifers. The BLV protein gp51 was neither detected by Reinacher et al. (1989), in the uterus of ten serologically positive cows, nor by Yaguiu et al. (2008), in four females naturally infected with BLV.

BLV proviral DNA was detected in the uterus of $54.5 \%(24 / 44)$ of the animals that were serologically positive (Table 1). The uterus of BLV infected animals is a common place for development of lymphosarcomas. Burton et al. (2010) found that $38 \%(40 / 105)$ of the animals with neoplasias that are analyzed by necropsy have lymphosarcomas in the uterus. Silva et al. (2008) reported the case of an animal in Brazil that was infected with BLV and developed tumor masses in several organs, including the uterus. Somura et al. (2014) found that the virus copy number was higher in lymphoid organs with lymphosarcoma than in asymptomatic BLV infected animals. This study did not assess if animals that tested positive in the uterine tissue had any histological alteration. Therefore, it remains unknown why BLV is present in the uterus of some seropositive cows and not others.

Table 1. Comparison of serology and PCR results in BLV uterine tissue.

\begin{tabular}{cccc}
\hline & $\begin{array}{c}\text { Positive } \\
\text { Serology }\end{array}$ & $\begin{array}{c}\text { Negative } \\
\text { Serology }\end{array}$ & Total \\
\hline Positive PCR & 24 & 0 & 24 \\
Negative PCR & 20 & 2 & 22 \\
\hline Total & 44 & 2 & 46 \\
\hline
\end{tabular}

Sensitivity: $54.5 \% \quad \mathrm{IC}_{95 \%}(54.5 \%-38.8 \%)$ Specificity: $100 \%$ $\mathrm{IC}_{95 \%}(15.8-100 \%)$. 
Presence of the agent in the uterus did not affect the incidence of reproductive problems (Table 2). The role of the agent in reproduction remains controversial, probably due to the heterogeneous clinical presentation of the disease in herds (DA et al., 1993). Future studies should address what are the consequences of BLV presence in the uterus of naturally infected animals.

Table 2. Detection of proviral DNA from BLV in the uterine tissue for each experimental group.

\begin{tabular}{cc}
\hline $\begin{array}{c}\text { Experimental } \\
\text { group }\end{array}$ & $\begin{array}{c}\text { BLV proviral DNA in the uterine } \\
\text { tissue }\end{array}$ \\
\hline Group 1 $(n=23)$ & $47.8 \% \%^{\mathrm{a}}(11 / 23)$ \\
Group 2 $(n=23)$ & $56.5 \% \%^{\mathrm{a}}(13 / 23)$ \\
\hline Total $(n=46)$ & $52.2 \%(24 / 46)$ \\
\hline
\end{tabular}

Same column letters indicate non-statistically significant differences, according to Fisher's exact test $(\mathrm{p}>0.05)$. Group 1: Animals with reproductive problems. Group 2: Animals without reproductive problems.

\section{Conclusion}

BTV was not detected in the uterus of any cow serologically positive for BTV. In contrast, BLV was detected in the uterine tissue of cows serologically positive for BLV. Of note, this virus was detected regardless of the existence of reproductive problems. This work proves that BLV is present in the uterus of naturally infected cows. Future studies should assess how the virus influences the reproductive performance of these animals.

\section{Acknowledgements}

The authors would like to thank the Universidade Federal de Minas Gerais (UFMG), the Empresa de Pesquisa Agropecuária de Minas Gerais (EPAMIG), the Empresa Brasileira de Pesquisa Agropecuária (EMBRAPA - Gado de Leite), and the partnership with the Laboratório Nacional Agropecuário (LANAGRO - MG/
MAPA). This study was financed by the Conselho Nacional de Desenvolvimento Científico e Tecnológico (CNPq), the Fundação de Amparo a Pesquisa de Minas Gerais (FAPEMIG) and INCTPecuária.

\section{References}

BIELANSKI, A.; ALGIRE, J.; LALONDE, A.; NADINDAVIS, S. Transmission of bovine viral diarrhea virus (BVDV) via in vitro-fertilized embryos to recipients, but not to their offspring. Theriogenology, Los Altos, v. 71, n. 3, p. 499-508, 2009.

BRASIL. Ministério da Agricultura, Pecuária e Abastecimento. Programa Nacional de Controle e Erradicação da Brucelose e Tuberculose Animal. Brasília: MAPA/SDA/DSA, 2006. 181p. Disponível em: $<$ http://www.agricultura.gov.br/arq_editor/file/Aniamal/ programa $\% 20$ nacional $\% 20$ sanidade $\% 20$ brucelose/ Manual\%20do\%20PNCEBT\%20-\%20Original.pdf>. Acesso em: 26 maio 2016.

BRENNER, J.; VAN-HAAM, M.; SAVIR, D.; TRAININ, $Z$. The implication of BLV infection in the productivity, reproductive capacity and survival rate of a dairy cow. Veterinary Immunology and Immunopathology, Amsterdam, v. 22, n. 3, p. 299-305, 1989.

BROWN, C. C.; RHYAN, J. C.; GRUBMAN, M. J.; WILBUR, L. A. Distribution of bluetongue virus in tissues of experimentally infected pregnant dogs as determined by in situ hybridization. Veterinary Pathology, Thousands Oaks, v. 33, n. 3, p. 337-340, 1996.

BURTON, A. J.; NYDAM, D. V.; LONG, E. D.; DIVERS, T. J. Signalment and clinical complaints initiating hospital admission, methods of diagnosis, and pathological findings associated with bovine lymphosarcoma (112 cases). Journal of Veterinary Internal Medicine, Philadelphia, v. 24, n. 4, p. 960-964, 2010.

COETZEE, P.; STOKSTAD, M.; MYRMEL, M.; MUTOWEMBWA, P.; LOKEN, T.; VENTER, E. H.; VAN VUUREN, M. Transplacental infection in goats experimentally infected with a European strain of bluetongue virus serotype 8 . Veterinary Journal, London, v. 197, n. 2, p. 335-341, 2013.

D'ANGELINO, J. L.; GARCIA, M.; BIRGEL, E. H. Productive and reproductive performance in cattle infected with bovine leukosis virus. The Journal of Dairy Research, London, v. 65, n. 4, p. 693-695, 1998. 
DA, Y.; SHANKS, R. D.; STEWART, J. A.; LEWIN, H. A. Milk and fat yields decline in bovine leukemia virusinfected Holstein cattle with persistent lymphocytosis. Proceedings of the National Academy of Sciences of the United States of America, Washington, v. 90, n. 14, p. 6538-6541,1993.

DE LA CONCHA-BERMEJILLO, A.; ODEON, A.; BONDURANT, R. H.; OSBURN, B. I. Experimental infection of pregnant cattle with bluetongue virus serotype 11 between postbreeding days 21 and 48. Journal of Veterinary Diagnostic Investigation, Columbia, v. 5, n. 3, p. 329-335, 1993.

DISKIN, M. G.; MORRIS, D. G. Embryonic and early foetal losses in cattle and other ruminants. Reproduction in Domestic Animals, Berlin, v. 43, n. 2, p. 260-267, 2008.

ELBERS, A. R.; VAN DER SPEK, A. N.; VAN RIJN, P. A. Epidemiologic characteristics of bluetongue virus serotype 8 laboratory-confirmed outbreaks in The Netherlands in 2007 and a comparison with the situation in 2006. Preventive Veterinary Medicine, Amsterdam, v. 92, n. 1-2, p. 1-8, 2009.

FERREIRA, A. M.; SÁ, W. F.; VETROMILA, M. A. M. Ovulação e gestação de vacas mestiças lado de maior frequencia. Pesquisa Agropecuária Brasileira, Seropédica, v. 23, n. 4, p. 435-437, 1988.

HEALD, M. T. S.; WALTNER-TOEWS, D.; JACOBS, R. M.; MCNAB, W. B. The prevalence of anti-bovine leukemia virus antibodies in dairy cows and associations with farm management practices, production and culling in Ontario. Preventive Veterinary Medicine, Amsterdam, v. 14, n. 1-2, p. 45-55, 1992.

HUBER, N. L; DIGIACOMO, R. F.; EVERMANN, J. F.; STUDER, E. Bovine leukemia virus infection in a large Holstein herd: cohort analysis of the prevalence of antibody-positive cows. American Journal of Veterinary Research, Chicago, v. 42, n. 9, p. 1474-1476, 1981.

JACOBS, R. M.; HEENEY, J. L.; GODKIN, M. A.; LESLIE, K. E.; TAYLOR, J. A.; DAVIES, C.; VALLI, V. E. Production and related variables in bovine leukaemia virus-infected cows. Veterinaty Research Communications, Amsterdam, v. 15, n. 6, p. 463-474, 1991.

KALE, M.; BULUT, O.; YAPKIC, O.; GULAY, M. S.; PEHLIVANOGLU, F.; ATA, A.; YAVRU, S. Effects of subclinical bovine leukemia virus infection on some production parameters in a dairy farm in southern Turkey. Journal of the South African Veterinary Association, Pretoria, v. 78, n. 3, p. 130-132, 2007.
KLINTEVALL， K.; BALAGGI-PORDÁNY， A.; NÄSLUND, K.; BELÁK, S. Bovine leukaemia virus: Rapid detection of proviral DNA by nested PCR in blood and organs of experimentally infected calves. Veterinary Microbiology, Amsterdam, v. 42, n. 2-3, p. 191-204, 1994.

LEE, J. I.; KIM, I. H. Pregnancy loss in dairy cows: the contributing factors, the effects on reproductive performance and the economic impact. Journal of Veterinary Science, Seoul, v. 8, n. 3, p. 283-288, 2007.

MARCEAU, A.; MADOUASSE, A.; LEHÉBEL, A.; VAN SCHAIK, G.; VELDHUIS, A.; VAN DER STEDE, Y.; FOURICHON, C. Can routinely recorded reproductive events be used as indicators of disease emergence in dairy cattle? An evaluation of 5 indicators during the emergence of bluetongue virus in France in 2007 and 2008. The Journal of Dairy Research, London, v. 97, n. 10, p. 6135-6150, 2014.

MELLOR, P. S.; WITTMANN, E. J. Bluetongue virus in the Mediterranean Basin 1998 - 2001. Veterinary Journal, London, v. 164, n. 1, p. 20-37, 2002.

MILLER, J. M.; MILLER, L. D.; OLSON, C.; GILLETE, K. G. Virus-like particles in phytohemagglutininstimulated lymphocyte cultures with reference to bovine lymphosarcoma. Journal of the National Cancer Institute, Washington, v. 43, n. 6, p. 1297-1305, 1969.

MILLER, J. M.; VAN DER MAATEN, M. J. Serologic detection of Bovine Leukemia Vírus infection. Veterinary Microbiology, Amsterdam, v. 1, n. 2-3, p. 195-202, 1976.

NUSINOVICI, S.; SEEGERS, H.; JOLY,A.; BEAUDEAU, F.; FOURICHON, C. Increase in the occurrence of abortions associated with exposure to the Bluetongue virus serotype 8 in naïve dairy herds. Theriogenology, Los Altos, v. 78, n. 5, p. 1140-1151, 2012a.

Quantification and at-risk period of decreased fertility associated with exposure to bluetongue virus serotype 8 in naïve dairy herds. Journal of Dairy Science, Champaign, v. 95, n. 6, p. 3008-3020, 2012 b.

OLIVEIRA, T. F. P.; FONSECA JUNIOR, A. A.; CAMARGOS, M. F.; OLIVEIRA, A. M. de; COTORELLO, A. C. P.; SOUZA, R. A.; ALMEIDA, I. G. de; HEINEMANN, M. B. Detection of contaminants in cell cultures, sera and trypsin. Biologicals, London, v. 41 n. 6, p. 407-414, 2013.

PEARSON, J. E.; JOCHIM, M. M. Protocol of the immunodiffusion test for bluetongue. In: ANNUAL PROCEEDINGS OF AMERICAN ASSOCIATION VETERINARY LABORATORY DIAGNOSTICANS, 22., 1979, Visalia. Proceedings...Visalia: American Association Veterinary Laboratory Diagnosticans, 1979. 
POLLARI, F. L.; WANGSUPHACHART, V. L.; DIGIACOMO, R. F.; EVERMANN, J. F. Effects of Bovine Leukemia virus infection on production and reproduction in Dairy Cattle. Canadian Journal of Veterinary Research, Ottawa, v. 56, n. 4, p. 289-295, 1992.

REINACHER, M.; THURMOND, M. C.; ONUMA, M.; PORTETELLE, D.; PICANSO, J.; THEILEN, G. H. Immunohistological demonstration of Virus and Tumor associated antigens in tissues in Experimental and Spontaneous Bovine Leukemia Virus (BLV) Infection. Veterinary Immunology and Immunopathology, Amsterdam, v. 22, n. 3, p. 223-231, 1989.

SANTMAN-BERENDS, I. M.; HAGE, J. J.; VAN RIJN, P. A.; STEGEMAN, J. A.; VAN SCHAIK, G. Bluetongue virus serotype 8 (BTV-8) infection reduces fertility of Dutch dairy cattle and is vertically transmitted to offspring. Theriogenology, Los Altos, v. 74, n. 8, p. 1377-1384, 2010.

SANTOS, J. E.; THATCHER, W. W.; CHEBEL, R. C.; CERRI, R. L.; GALVÃO, K. N. The effect of embryonic death rates in cattle on the efficacy of estrus synchronization programs. Animal Reproduction Science, Amsterdam, v. 82-83, p. 513-535, 2004.

SHAW, A. E.; MONAGHAN, P.; ALPAR, H. O.; ANTHONY, S.; DARPEL, K. E.; BATTEN, C. A.; GUERCIO, A; ALIMENA, G.; VITALE, M.; BANKOWSKA, K.; CARPENTER, S.; JONES, H.; OURA, C. A.; KING, D. P.; ELLIOTT, H.; MELLOR, P. S.; MERTENS, P. P. Development and initial evaluation of a real-time RT-PCR assay to detect bluetongue virus genome segment 1. Journal of Virological Methods, Amsterdam, v. 145, n. 2, p. 115-126, 2007.

SILVA, F. C.; FONTANA, I.; MEIRELLES, F. C.; RUGGIERO, A. P. M.; BENATO, N.; BORGES, J. R. J. Ocorrência de Leucoze Enzoótica Bovina na forma de linfossacormas nos Distrito Federal: relato de caso. Arquivos do Instituto Biológico, São Paulo, v. 75, n. 4, p. 507-512, 2008.
SOMURA, Y.; SUGIYAMA, E.; FUJIKAWA, H.; MURAKAMI, K. Comparison of the copy numbers of bovine leukemia virus in the lymph nodes of cattle with enzootic bovine leukosis and cattle with latent infection. Archives of virology, Wien, v. 159, n. 10, p. 2693-2697, 2014.

VANLEEUWEN, J. A.; HADDAD, J. P.; DOHOO, I. R.; KEEFE, G. P.; TIWARI, A.; TREMBLAY, R. Associations between reproductive performance and seropositivity for bovine leukemia virus, bovine viraldiarrhea virus, Mycobacterium avium subspecies paratuberculosis, and Neospora caninum in Canadian dairy cows. Preventive Veterinary Medicine, Amsterdam, v. 94, n. 1-2, p. 54-64, 2010.

WALSH, S. W.; WILliams, E. J.; EVANS, A. C. A. A review of the causes of poor fertility in high milk producing dairy cows. Animal Reproduction Science, Amsterdam, v. 123, n. 3-4, p. 127-138, 2011.

WORLD ORGANISATION FOR ANIMAL HEALTH OIE. Manual of diagnostic tests and vaccines for terrestrial animals. Paris: Office International des Epizooties, 2010. Available at: <http://www.oie.int/manual-of-diagnostictests-and-vaccines-for-terrestrial-animals/>. Accessed at: 26 maio 2016.

YAGUIU, A.; DAGLI, M. L.; BIRGEL JÚNIOR, E. H.; ALVES REIS, B. C.; FERRAZ, O. P.; PITUCO, E. M.; FREITAS, A. C.; BECAK, W.; STOCCO, R. C. Simultaneous presence of bovine papillomavirus and bovine leukemia virus in different bovine tissues: in situ hybridization and cytogenetic analysis. Genetics and Molecular Research, Ribeirão Preto, v. 7, n. 2, p. 497487, 2008.

ZANELLA, G.; DURAND, B.; SELLAL, E.; BREARD, E.; SAILlEAU, C.; ZIENTARA, S.; BATTEN, C. A.; MATHEVET, P.; AUDEVAL, C. Bluetongue virus serotype 8: Abortion and transplacental transmission in cattle in the Burgundy region, France, 2008-2009. Theriogenology, Los Altos, v. 77, n. 1, p. 65-72, 2012. 
